\title{
Annual South American forest loss estimates based on passive microwave remote sensing (1990-2010)
}

\author{
M. J. E. van Marle ${ }^{1}$, G. R. van der Werf ${ }^{1}$, R. A. M. de Jeu ${ }^{1, a}$, and Y. Y. Liu ${ }^{2}$ \\ ${ }^{1}$ Faculty of Earth and Life Sciences, Vrije Universiteit Amsterdam, Amsterdam, the Netherlands \\ ${ }^{2}$ ARC Centre of Excellence for Climate System Science \& Climate Change Research Centre, \\ University of New South Wales, Sydney, Australia \\ anow at: VanderSat B. V., Space Technology Centre, Noordwijk, the Netherlands \\ Correspondence to: M. J. E. van Marle (m.j.e.van.marle@vu.nl)
}

Received: 1 July 2015 - Published in Biogeosciences Discuss.: 23 July 2015

Revised: 11 December 2015 - Accepted: 13 January 2016 - Published: 2 February 2016

\begin{abstract}
Consistent forest loss estimates are important to understand the role of forest loss and deforestation in the global carbon cycle, for biodiversity studies, and to estimate the mitigation potential of reducing deforestation. To date, most studies have relied on optical satellite data and new efforts have greatly improved our quantitative knowledge on forest dynamics. However, most of these studies yield results for only a relatively short time period or are limited to certain countries. We have quantified large-scale forest loss over a 21-year period (1990-2010) in the tropical biomes of South America using remotely sensed vegetation optical depth (VOD). This passive microwave satellitebased indicator of vegetation water content and vegetation density has a much coarser spatial resolution than optical data but its temporal resolution is higher and VOD is not impacted by aerosols and cloud cover. We used the merged VOD product of the Advanced Microwave Scanning Radiometer (AMSR-E) and Special Sensor Microwave Imager (SSM/I) observations, and developed a change detection algorithm to quantify spatial and temporal variations in forest loss dynamics. Our results compared reasonably well with the newly developed Landsat-based Global Forest Change (GFC) maps, available for the 2001 onwards period $\left(r^{2}=0.90\right.$ when comparing annual countrylevel estimates). This allowed us to convert our identified changes in VOD to forest loss area and compute these from 1990 onwards. We also compared these calibrated results to PRODES $\left(r^{2}=0.60\right.$ when comparing annual state-level estimates). We found that South American forest exhibited substantial interannual variability without a clear trend during
\end{abstract}

the 1990s, but increased from 2000 until 2004. After 2004, forest loss decreased again, except for two smaller peaks in 2007 and 2010. For a large part, these trends were driven by changes in Brazil, which was responsible for $56 \%$ of the total South American forest loss area over our study period according to our results. One of the key findings of our study is that while forest loss decreased in Brazil after 2005, increases in other countries partly offset this trend suggesting that South American forest loss as a whole decreased much less than that in Brazil.

\section{Introduction}

There are large uncertainties in the spatial and temporal patterns of forest loss and associated fluxes of carbon in the tropical ecosystems (Grainger, 2008; Hansen et al., 2010; Malhi, 2010; Pan et al., 2011). Forest loss can be either natural, for example due to wind-throw or natural fires, or anthropogenic, usually labelled deforestation. Deforestation carbon emissions are a significant but declining fraction of total anthropogenic $\mathrm{CO}_{2}$ emissions (van der Werf et al., 2009). In Amazonia, tropical deforestation was the main source of carbon emissions (Morton et al., 2008), at least during their 2003 to 2007 study period. More than half of the total forest carbon is stored in tropical intact forests, of which more than $50 \%$ is stored in living biomass, about a third in the soil, with the remaining carbon being stored in dead wood and litter (Pan et al., 2011). In South America, deforestation is mainly caused by the expansion of agriculture and the area 
used for cattle ranging (FAO, 2006; Fearnside, 2005; Geist and Lambin, 2002), and the continent is responsible for almost half of the tropical deforestation emissions (Harris et al., 2012; Pan et al., 2011). Over the last 30 years soybean production has expanded rapidly in Amazonia, partly driven by improved yield-increasing and labour-saving technologies (Grau et al., 2005; Naylor et al., 2005).

Historically, the widely used data sets for forest area changes and timber harvesting in the 1980s and 1990s are the forest resource assessments (FRAs), as reported by countries to the United Nations Food and Agriculture Organization (UN FAO) (FAO, 2006), but which are known to suffer from issues regarding consistency (Grainger, 2008). Satellite observations overcome some of the issues found in earlier FAO data sets, because they systematically monitor in space and time. Over the last three decades several satellitebased deforestation data sets have been developed. Landsat satellite imagery is the longest operative option for monitoring vegetation. From 1972 through January 1999 the Landsat Multispectral Scanner (MSS) provided continuous data at a relatively high spatial resolution of $90 \mathrm{~m}$. For 1982 onwards the Landsat (Enhanced) Thematic Mapper ((E)TM) provides vegetation cover at an even higher spatial resolution of $30 \mathrm{~m}$, with a 16-day revisit time. However, the effective temporal resolution is much lower because of issues related to cloud cover, which often persists not only in the wet season but also during the dry season between June and November in the Amazon basin south of the Equator (Costa and Foley, 1998). Therefore, these observations are mostly used in annual or multi-year analyses, but there is a need for alternative nonoptical data techniques to provide time series on a monthly or higher temporal resolution (Asner, 2001). Other widely used satellite data sets for vegetation are the Normalized Difference Vegetation Index (NDVI), often derived from the Advanced Very High Resolution Radiometer (AVHRR). NDVI is sensitive to canopy greenness (Anyamba and Tucker, 2005; Tucker et al., 2005; Zhu et al., 2013). This data set has a higher temporal, but coarser spatial resolution than Landsat, and is also sensitive to aerosols and cloud cover. Other vegetation data sets that can capture vegetation dynamics are for example the observations based on long-wavelength radar backscatter (Joshi et al., 2015), where deforestation, forest degradation and the follow-up vegetation cover could be captured, and those based on observations from the SeaWinds Ku-band scatterometer (Frolking et al., 2012), which have been shown to capture gross forest loss in the Tropics. Also lidar data can be used to estimate forest biomass, and can thus capture vegetation dynamics (Mitchard et al., 2012). Data availability for radar and lidar data sets is usually from 1998 onwards.

Over the past years, the number of data sets quantifying vegetation dynamics, carbon stocks, and other relevant vegetation quantities on both the global and regional scales has thus increased substantially, often using Landsat and AVHRR data but also other data sources including the
Moderate-resolution Imaging Spectroradiometer (MODIS, launched in 1999 on board of Terra and in 2002 on Aqua), Medium Resolution Imaging Spectrometer (MERIS, 20022012), and Satellite Pour l'Observation de la Terre Vegetation Program (SPOT VGT, from 1986 onboard different satellites) (Achard et al., 2014; Baccini et al., 2012; Broich et al., 2011; Ernst et al., 2013; Eva et al., 2012; Frolking et al., 2012; Jones et al., 2011; de Jong et al., 2013; Kim et al., 2015; Koh et al., 2011; Mayaux et al., 1998; Morton et al., 2005; Potapov et al., 2012; Saatchi et al., 2011; Verbesselt et al., 2012; Verhegghen et al., 2012; Wasige et al., 2012).

One of the regions most closely monitored is the Brazilian Legal Amazon, where the Brazilian National Institute for Space Research (INPE) developed the Program for Deforestation Assessment in the Brazilian Legal Amazon with Satellite Imagery (PRODES). PRODES estimates annual deforestation since 1988 based on a multi-data approach mostly based on Landsat data but also the China-Brazil Earth Resource Satellite (CBERS-2B) and UK-DCM2 from the Disaster Monitoring Constellation International Imaging (DMCii) (Shimabukuro et al., 1998). Other efforts include the recently published global maps of global forest gain and loss for the 2001-2012 period also using Landsat data (Hansen et al., 2013).

In addition to the previously mentioned data sets mostly based on visible and infrared wavelengths, passive microwave observations can also be used to characterize vegetation dynamics. Vegetation optical depth (VOD) is a vegetation attenuation parameter in the microwave domain. This parameter was first described by Kirdiashev et al. (1979) in a zero-order radiative transfer model for vegetation canopies. VOD is primarily sensitive to the vegetation water content and also captures information about vegetation structure (Jackson and Schmugge, 1991; Kerr and Njoku, 1990; Kirdiashev et al., 1979).

The longer wavelengths of passive microwave enables sensitivity of VOD not only to the leafy part, but also to woody parts of vegetation (Andela et al., 2013). Therefore VOD yields information about both the photosynthetic and nonphotosynthetic parts of aboveground vegetation, based on the water content (Jones et al., 2011; Shi et al., 2008). VOD is shown to be highly correlated with aboveground biomass (Liu et al., 2011a; Owe et al., 2001) and thus yields information about the net forest loss - the balance between decreases in forest loss due to deforestation and degradation and increases in forest extend due to regrowth or thickening. Furthermore, the advantage of low-frequency $(<20 \mathrm{GHz}) \mathrm{mi}-$ crowave remote sensing is that aerosols and clouds have a negligible effect on the observations, so even areas with regular cloud cover are observed frequently, which makes it suitable to use for global vegetation monitoring at daily time steps.

Comparing AVHRR NDVI and passive microwave-based VOD data sets with a record longer than 20 years, Liu et al. (2011a) showed that both data sets had similar seasonal 
cycles. VOD however, also showed interannual variations in regions with water stress, which correspond for a large part to variations in precipitation. VOD was more sensitive to changes in woody vegetation compared to NDVI, whereas NDVI was more sensitive to herbaceous changes (Andela et al., 2013). This is the result of NDVI being more sensitive to canopy greenness (Myneni et al., 1995) and VOD being more sensitive to water content, relatively speaking. Thus, when forest is converted to large-scale cropland, the canopy greenness does not necessarily drop, whereas the total water content of the aboveground biomass decreases (Liu et al., 2011a).

The main disadvantage of these low-frequency passive observations is that a large footprint is needed to yield an observable signal, making this data set most suitable for large regional and continental-scale studies. These retrievals therefore have a relatively coarse resolution, compared to observations in the visible and near-infrared parts of the spectrum. Furthermore, the presence of open water regions affects the signal. This, in combination with the large footprint of the gridded product, may lead to underestimation of VOD when grid cells are close to large open waters (Jones et al., 2011). VOD is retrieved from several satellite sensors. The observations retrieved from the Advanced Microwave Scanning Radiometer (AMSR-E) and Special Sensor Microwave Imager (SSM/I) have been merged to one data set with a spatial resolution of $0.25^{\circ}$, based on Cumulative Distribution Function (CDF) matching. This merged VOD data set has been used to study vegetation dynamics in different ecosystems on both global and regional scales (Andela et al., 2013; Liu et al., 2012, 2013, 2015; Poulter et al., 2014; Zhou et al., 2014). Guan et al. (2012) compared QuickScat Ku-band backscatter coefficients $(\mathrm{dB})$ with VOD and NDVI and noted that the three data sets are comparable, but that $\mathrm{dB}$ shows abnormal high values when more bare soil is present in the pixel.

This paper aims to estimate large-scale forest loss in South America. We show how the merged VOD product can be used to estimate forest loss for South America on a countrylevel scale, but we also point towards limitations of our approach and the data set. The main novelty of our approach is the relatively long (1988-2011) time series based on a consistent data stream. We detail how we translated the VOD signal to forest loss area by calibrating our results to the Global Forest Change maps of Hansen et al. (2013), which are subsequently compared to the Landsat-derived PRODES data set. We provide a country-level analysis of the newly derived maps, and zoom in on Brazil to present a state-level analysis of forest loss over the 1990-2010 period. This time period is somewhat shorter than the time span of the VOD data set due to the requirements of the change detection algorithm we developed.

\section{Data sets}

In this section we describe the data sets we used in our analysis. First, we give more information on the VOD data set that is used for our estimation of forest loss (Sect. 2.1), followed by describing the two data sets we used for comparison: the Global Forest Change (GFC, Sect. 2.2), which besides being used for comparing the spatio-temporal variability is also used to translate our results to area estimates, and the PRODES data set (Sect. 2.3).

\subsection{Vegetation optical depth}

Forest loss estimates in this paper are based on VOD, which is derived from passive microwave remote sensing. Passive microwave remote sensing differs from active microwave remote sensing (radar) in the sense that radar transmits a longwavelength microwave signal through the atmosphere and then records the amount of energy backscattered, whereas passive systems record electromagnetic energy that was reflected or emitted from the surface of the Earth. VOD was first introduced by Kirdiashev et al. (1979), and then modified to be used in the well-known omega-tau model (Mo et al., 1982). Kirdiashev et al. (1979) already described the relationship between VOD and vegetation water content. This relationship was further simplified by Jackson and Schmugge (1991) where the vegetation water content was directly related to VOD. The algorithm of the VOD data set we used here is based on the land parameter retrieval model (LPRM) (Meesters et al., 2005; Owe et al., 2001, 2008). LPRM is based on a radiative transfer model and solves simultaneously for soil moisture and VOD. It can be applied to passive microwave sensors and has been used in numerous studies (see de Jeu et al., 2014). VOD can be used to estimate biomass (Liu et al., 2015), and changes therein correspond to net forest loss (equals the net sum of deforestation, degradation, and regrowth) in a $0.25^{\circ}$ grid cell.

The VOD time series used here is based on merging observations from two sensors (Liu et al., 2011a). The different observations come from SSM/I (1988-2007) and AMSR-E (July 2002-September 2011). These two sensors have different specifications regarding wavelength, viewing angle, and spatial footprint and therefore the absolute values of the retrieved VOD values differ. Their relative dynamics, however, are similar (Liu et al., 2011a). In the merging procedure the AMSR-E retrievals were used as a reference, because this product has the higher accuracy due to its relatively low frequency. The cumulative distribution frequency (CDF) matching technique was used for rescaling SSM/I to match AMSRE. For the period July 2002 through September 2011 AMSRE data are used. Before July 2002, SSM/I observations are used. Full details on the merging process can be found in Liu et al. (2011a, b). In this study, we used monthly values, which were derived from the merged VOD data set (version January 2015) by averaging the daily data fields, and were resampled 
to $0.25^{\circ}$. VOD observations are dimensionless and their values range from 0 to 1.5 . At a certain point, when VOD values exceed 0.8 , the vegetation becomes so dense that the soil component in the radiative transfer becomes very small. This is a gradual process and when VOD values are higher than 0.8 additional checks are necessary before using the values in vegetation studies. When VOD exceeds 1.2, smaller-scale variations in the vegetation canopy cannot be captured anymore (Owe et al., 2001).

\subsection{Global Forest Change (GFC)}

Hansen et al. (2013) released early 2014 the Global Forest Change (GFC) project gridded data set, which is probably the most data-rich and computer-intensive production of global forest change maps. It contains annual maps over the time period $2001-2013$ at a $30 \mathrm{~m}$ resolution. The maps are based on the $30 \mathrm{~m}$ Landsat 7 Enhanced Thematic Mapper Plus (ETM+) scenes, which were resampled and normalized to create a gridded data set of cloud-free image observations. Forest loss is defined in GFC as a change from forest to non-forest state, comprising deforestation and degradation. In our analysis, we used the annual forest loss data set and reprocessed these to the $0.25^{\circ}$ resolution of our analysis by summing the $30 \mathrm{~m}$ values. While regrowth is detected and reported, we focused on the forest loss data when we used GFC for comparison; regrowth is thus not included in our analysis of GFC. We did not include the 2000 forest cover map as mask for forested areas to avoid omitting areas that were deforested before 2000 .

\subsection{PRODES deforestation}

The Brazilian space agency INPE provides annual gross deforestation maps of the Brazilian Legal Amazon within the Program for Deforestation Assessment in the Brazilian Legal Amazonia (PRODES). INPE defines deforestation as the gross deforestation rate of the conversion of intact forests (old growth forest) to a different land use such as agropasture, wood exploration areas, and silviculture. Degradation and deforestation of regenerating secondary forests are not monitored by PRODES (INPE, 2013).

Although PRODES covers a relatively long time period, the method of detection of deforestation has changed over time. For the time period 1988-2002 the detection of deforestation polygons was done by visual interpretation of Landsat 5 and Landsat 7 scenes. More recently these polygons were manually digitized in the PRODES Analog project (INPE, 2013). After 2002, PRODES started to use digital image processing and visual interpretation of Landsat bands 3, 4, and 5, creating and interpreting images of soil, shade, and vegetation fractions (INPE, 2013; Shimabukuro et al., 1998). Deforestation is reported once per year in August based on changes over the previous 12-month period. Deforestation within PRODES is defined as clear-cut areas of pri-

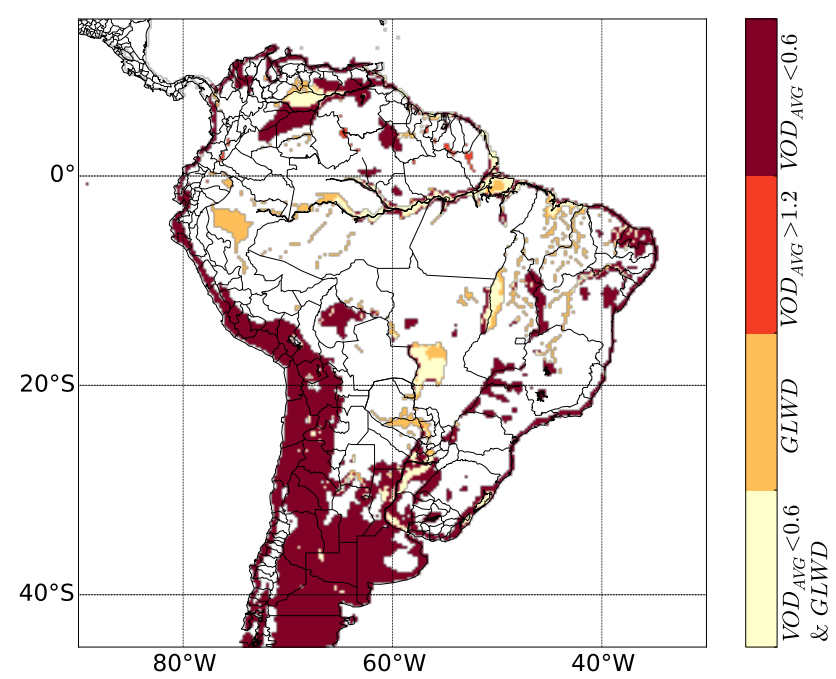

Figure 1. Grid cells that were excluded from our analysis: VOD avg: grid cells with an average VOD that is either above 1.2 or below 0.6 and thus outside the usable range for our study. GLWD: grid cells containing more than $50 \%$ open water, which makes the VOD signal unreliable. Both: grid cells containing more than $50 \%$ open water and where VOD is outside the usable range.

mary forests exceeding 6.25 ha. Because of this threshold in detection omitting deforestation smaller than 6.25 ha, INPE reports that underestimation of deforestation occurs. Furthermore, there may be unobserved areas due to cloud cover in the Landsat images during the time period of visual interpretation until 2005 (INPE, 2013).

\section{Methods}

In this section we will first explain the pre-processing of the data (Sect. 3.1), and then describe the methodology used to detect forest loss (Sect. 3.2). Finally, we will explain how the detected changes were converted to forest loss area (Sect. 3.3)

\subsection{Data selection}

We aimed to estimate gross forest loss for each $0.25^{\circ}$ pixel on an annual basis, which will be explained in Sect. 3.2. We first filtered the available data to circumvent false detections related to the use of microwave data. The excluded grid cells are shown in Fig. 1, and the data exclusion was based on two criteria:

1. Average VOD values should be below 1.2. This is to prevent false detection in densely vegetated areas without clear forest loss. The value was based on Owe et al. (2001), who stated that VOD values larger than 1.2 cannot be used to detect significant vegetation changes. When vegetation is very dense, the VOD signal becomes noisy and potential changes in forest cover cannot be detected anymore. These pixels are mainly found 

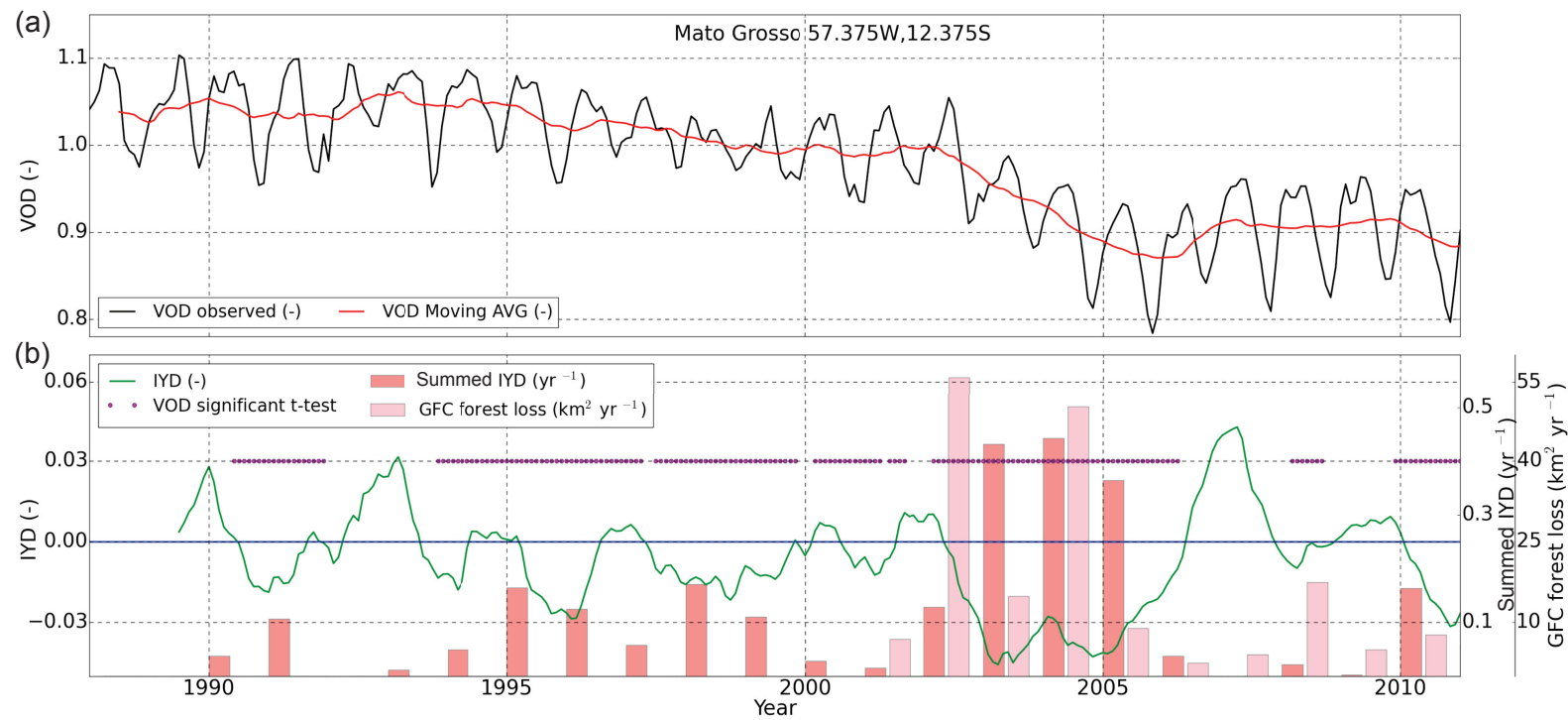

Figure 2. Example $0.25^{\circ}$ grid cell in the Brazilian state of Mato Grosso. A: Observed monthly VOD signal and 19-month moving average (VOD MovingAVG). B: Interyearly difference (IYD), whether it met the $t$ test criteria, and annually summed IYD values taking only negative values into account. For comparison the corresponding GFC values are also given.

in the middle of the Amazon forest, where forest loss rates are low. In addition, we excluded grid cells where VOD values were on average below 0.6 to maintain a focus on forested grid cells. Also when forest loss occurs in the early stages of the time series, the average VOD value will not be below this limit of 0.6. This value was based on the comparison between VOD and MODISbased Vegetation Continuous Fields (VCF), which provides information about the fraction tree cover in a pixel. Our VOD threshold of 0.6 corresponds to $10 \%$ tree cover for two-thirds of the pixels, a percentage sometimes used to define forest (Saatchi et al., 2011; UNFCCC, 2006) although there is no consensus about this definition.

2. Large open water should be avoided. Open water affects microwave emissions and can lead to underestimation of VOD (Jones et al., 2011). Therefore $0.25^{\circ}$ grid cells, which contain more than $50 \%$ open water based on the Global Lakes and Wetlands Database (GLWD, Lehner and Döll, 2004), were masked out.

We excluded these grid cells also from GFC and PRODES data when we compared the results. Therefore, total South American forest loss over 2001-2010 for GFC reported here are on average $4 \%$ lower than without the data exclusion, which also gives an indication of our underestimation due to masking out of these grid cells.

\subsection{Detection of forest loss}

Our method is a change detection method based on the principle that VOD is directly related to the aboveground living biomass. Therefore persistent changes in VOD over time are related to changes in biomass (Liu et al., 2015), for example when forest is converted to non-forest. Basically we track the full time series and inspect whether there are sudden drops in the signal that could be the result of forest loss. Our approach is based on four steps and explained using an example grid cell located in the Brazilian state of Mato Grosso, where forest loss has been high during the 2000-2005 interval according to Hansen et al. (2010).

As a first step we deseasonalized the time series based on a

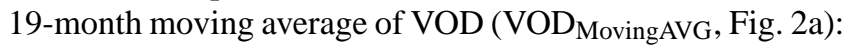

$\operatorname{VOD}_{\text {MovingAVG }}($ lat, long, $m)=$ Average $\left(\operatorname{VOD}_{\text {obs }}(\right.$ lat, long, $\left.m-9: m+9)\right)$

where lat, long, $m$ is the latitude (lat), longitude (long) and month $(m)$. With $m-9: m+9$ we refer to all data points 9 months before until 9 months after the specific month. This approach was preferred over taking out the seasonal cycle based on the average of all cycles because the seasonal cycle from forest and non-forest is different. In addition, a longer moving average masks part of the signal due to droughts or anomalous wet periods which also influence VOD. We also tested longer averaging windows (see Sect. 4.5 for details about the tested windows), but the results were relatively insensitive to this and it decreased the numbers of years over which we could report. In the example grid cell VOD $_{\text {MovingAVG }}$ decreased most strongly during 2002-2005 (Fig. 2a).

To estimate where forest loss potentially occurred and how this was partitioned over different year(s), in the second step we calculated the difference of VOD MovingAVG with the same variable 12 months earlier, and label this the inter-yearly- 
difference (IYD, Fig. 2b).

$$
\begin{aligned}
\operatorname{IYD}(\text { lat }, \text { long, } m) & =\operatorname{VOD}_{\text {MovingAVG }}(\text { lat }, \text { long, } m) \\
& -\operatorname{VOD}_{\text {MovingAVG }}(\text { lat }, \text { long, } m-12)
\end{aligned}
$$

When the IYD was below 0, this specific month was detected as a possible moment for forest loss. In the third step, we tested using a two-sided $t$ test whether IYD was negative because of forest loss, or because of other reasons, for example due to natural interannual variability related to rainfall. The first group of the $t$ test consisted of all VOD observations preceding the month where IYD was negative. The second group consisted of all other VOD observations from that moment until the end of the time series. When the $p$ value was smaller than 0.05 , we flagged the grid cell and month as forest loss (Fig. 2b). These three steps were done for every grid cell and month from October 1989 until January 2011.

In the fourth and final step, we calculated the sum of the absolute IYD values, which we will refer to as VOD $_{\text {outliers }}$ in the rest of this paper. This was done from 1990 through 2010 to get annual values (Fig. 2b).

\subsection{Conversion to area forest loss}

Our method yields the number of $\operatorname{VOD}_{\text {outliers }}$ per year for each grid cell, which is related qualitatively to the amount of forest loss and may thus yield insight into the spatial and temporal dynamics of forest loss. However, to go one step further and convert our results to the area of forest loss we calibrated our results to the gross forest loss estimates of GFC. Because of the large differences in spatial resolution ( $30 \mathrm{~m}$ for GFC and $0.25^{\circ}$ for VOD) and because our data set is most useful for large-scale assessments, we calibrated the conversion of the VOD outliers $_{\text {to }}$ area based on a country-level approach for the overlapping time period (2000-2010). In general, our method yields net forest loss per grid cell within one year, because we considered decreases in VOD, which is the net result of deforestation, forest degradation, and regrowth within a grid cell per year.

Because VOD and biomass are not linearly related, we binned VOD into five groups comprising the average VOD values between 0.6 and $1.2(0.6-0.7,0.7-0.8,0.8-0.9,0.9-$ 1.0 and $1.0-1.2$ ). The last bin was larger to arrive at more robust regression outcomes, because there are fewer grid cells with VOD above 1.0. For every bin we performed a Pearson regression (Pearson performed preferably, compared to Spearman) forced through the origin, with all VOD year related to the same GFC values. Based on the linear regression, we obtained a slope for each VOD bin, which was used to convert $\mathrm{VOD}_{\text {outliers }}$ to gross forest loss area per $0.25^{\circ}$ grid cell.

$$
\operatorname{VOD}_{\text {area forest loss }}(\text { year })=\sum_{\text {bin }=1}^{5} \operatorname{VOD}_{\text {outliers }}(\text { year, bin }) \times \text { slope }(\text { bin })
$$

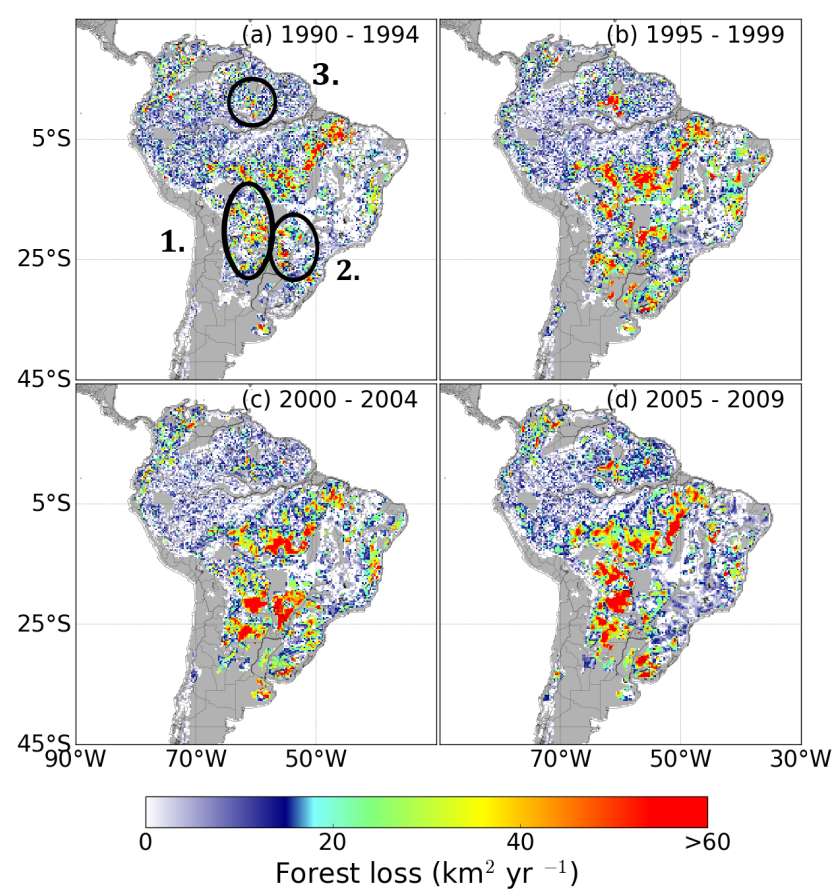

Figure 3. Forest loss extent based on the $\mathrm{VOD}_{\text {outliers }}$ for the 5-year epochs. Grey areas are masked out (Fig. 1).

\section{Results}

\subsection{Spatial extent}

The largest feature over our study period is the well-known arc of deforestation along the Southern edge of the Amazon basin (Fig. 3), showing high forest loss in every period. Highest forest loss was observed in the Brazilian states Mato Grosso, Pará, and Maranhão. However, forest loss rates were not uniform in space and time, Fig. 3 shows that forest loss rates have fluctuated with lowest forest loss observed during the 1995-1999 period and highest forest loss observed in the 2000-2004 period.

While forest loss in South America is most often associated with this arc of deforestation, also other regions experienced forest loss. One is the region extending from northern Argentina to Bolivia via Paraguay (Fig. 3a, label 1), also known as the Chaco region, showing high forest loss over the full time period. Forest loss in this region is expanding and increasing in intensity over time. Another region extends from the southeastern part of Paraguay into Brazil along the border of the Brazilian state Mato Grosso do Sul (Fig. 3a, label 2). During the 1995-1999 period forest loss was on the rise here and increased to a maximum during the 2000-2004 period, but decreased during the 2005-2009 epoch.

Finally, the region north of Manaus in the Brazilian states of Roraima and Amazonas (Fig. 3a, label 3) which partly consists of wooded savanna, also showed high forest loss. Here the forest loss increased and expanded during the 1990s 
Table 1. Statistics for the comparison between GFC forest loss $\left(\mathrm{km}^{2} \mathrm{yr}^{-1}\right)$ and IYD $\left(\mathrm{yr}^{-1}\right)$. This was done for all grid cells and when aggregating the grid cells in a country-level analysis. The coefficient of variation (CV in \%) was based on the Root Mean Square Error (RMSE in $\mathrm{km}^{2}$ ) between both data sets.

\begin{tabular}{lrrrr|rrr}
\hline VOD bin & \multicolumn{3}{c|}{ Based on all grid cells } & \multicolumn{3}{c}{ Country level } \\
\cline { 2 - 8 } & Slope & $r^{2}$ & CV (\%) & RMSE $\left(\mathrm{km}^{2}\right)$ & $r^{2}$ & CV (\%) & RMSE (km $\left.{ }^{2}\right)$ \\
\hline $0.6-0.7$ & 22.4 & 0.63 & 804 & 15.7 & 0.63 & 203 & 666 \\
$0.7-0.8$ & 34.8 & 0.52 & 163 & 3.7 & 0.84 & 122 & 586 \\
$0.8-0.9$ & 61.7 & 0.80 & 147 & 5.0 & 0.84 & 83 & 567 \\
$0.9-1.0$ & 79.4 & 0.72 & 134 & 4.7 & 0.88 & 92 & 684 \\
$1.0-1.2$ & 82.7 & 0.72 & 253 & 3.2 & 0.96 & 53 & 366 \\
\hline
\end{tabular}

with the biggest change between the first and second half of the 1990s. Forest loss stayed relatively stable during the first half of the 2000s. During the 2005-2009 time window some areas with intense forest loss in previous periods did not show up anymore, for example large parts of the arc of deforestation. Besides these three large regions, several smaller fluctuations occurred. These can mostly be seen in the southeastern Brazilian state Minas Gerais.

\subsection{Calibration with GFC}

We converted the summed $\mathrm{VOD}_{\text {outliers }}$ to a forest loss area according to Eq. (3), where the slopes varied between the five different bins (Table 1). The Pearson correlation on a grid-scale was lowest $\left(r^{2}=0.52\right)$ for the bin with the average VOD from 0.6-0.7. The other four bins had correlations ranging from $r^{2}=0.63$ to 0.80 (Table 1). The largest errors are found in the regions with dense vegetation and relatively little forest loss (Figs. 4 and 5). The RMSE on a grid-cell scale shows that the bin with the lowest average VOD values (0.6-0.7) has the highest error compared to GFC (Table 1).

On a country scale, the correlations per bin were higher with the lowest $\left(r^{2}=0.63\right)$ again for the bin with the lowest average VOD (0.6-0.7), and the four other bins had increasing correlations from $r^{2}=0.84$ to 0.96 (Table 1). The country-level comparison of our VOD outliers with GFC forest loss had a Pearson linear agreement of $r^{2}=0.90$ $(p<0.001)$. In Fig. 6 the country-level VOD and GFC forest loss area estimates are plotted against each other along with the $1: 1$ line. Most data points were reasonably close to this line, although VOD overpredicted forest loss towards the lower end of the spectrum. Especially in the countries with the lowest forest loss, including Surinam, Uruguay, French Guiana, and Guyana, our method yielded more forest loss than GFC. As a percentage of the available area per country (Table 2$)$ Uruguay $(0.65 \%)$, Surinam $(0.22 \%)$, French Guiana $(0.14 \%)$, and Guyana $(0.13 \%)$ also showed higher average forest loss over the overlapping time period based on VOD. Chile is on the other hand the country where VOD provides lower forest loss estimates for the overlapping time period $(-0.18 \%)$ compared to GFC. The country with the

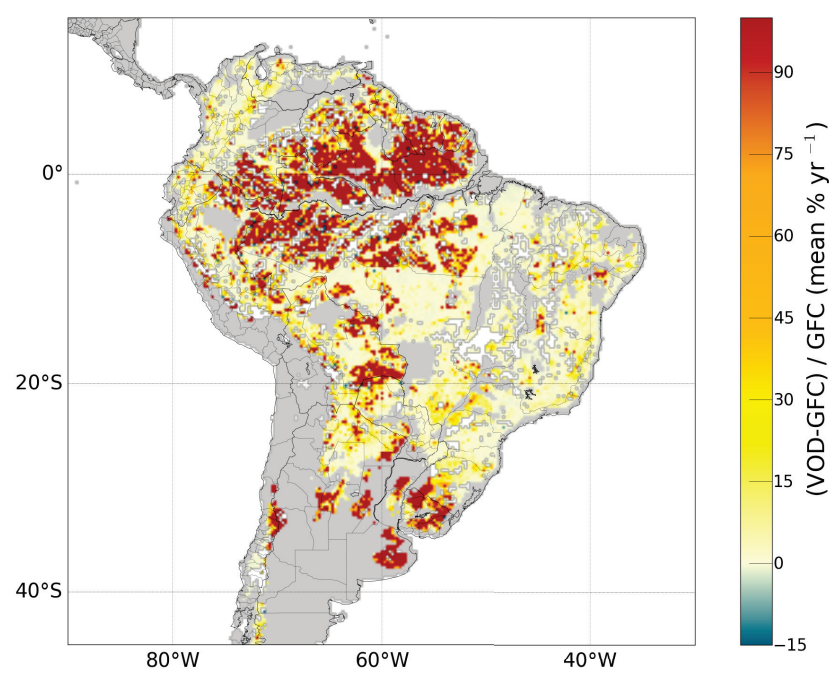

Figure 4. Error estimates for each grid cell. The error is defined as VOD minus GFC forest loss area expressed as a percentage of GFC for the overlapping time period. White indicates that both data sets had no forest loss.

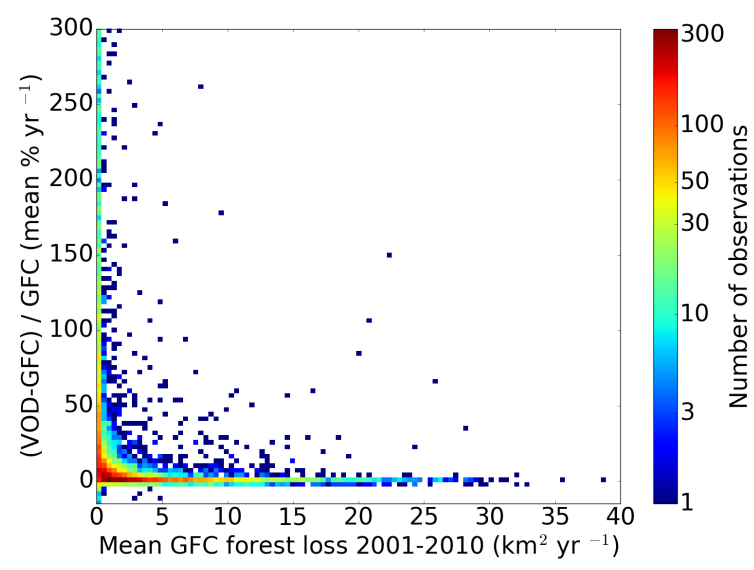

Figure 5. Error as a function of mean GFC forest loss, where the error is defined as VOD minus GFC forest loss area as a percentage of GFC for the overlapping time period. 
Table 2. Country-level forest loss estimates (total area, contribution to total South American forest loss, contribution of forest loss as a percentage of the masked-country area, as well as absolute and relative trends) for VOD and GFC for the overlapping time period (20012010). Asterisks indicate the significance, where ${ }^{*}=p>0.25 ;^{* *}=p<0.25 ;^{* * *}=p<0.05$.

\begin{tabular}{|c|c|c|c|c|c|c|c|c|c|c|}
\hline & \multicolumn{6}{|c|}{ Average forest loss 2001-2010 } & \multicolumn{4}{|c|}{ Slope 2001-2010 } \\
\hline & \multicolumn{2}{|c|}{ Absolute $\left(\mathrm{km}^{2} \mathrm{yr}^{-1}\right)$} & \multicolumn{2}{|c|}{$\begin{array}{l}\text { Percentage of total } \\
\text { forest loss area } \\
\text { (Absolute/Total) }(\%)\end{array}$} & \multicolumn{2}{|c|}{$\begin{array}{l}\text { Percentage of masked } \\
\text { country area }(\%)\end{array}$} & \multicolumn{2}{|c|}{ Absolute $\left(\mathrm{km}^{2} \mathrm{yr}^{-2}\right)$} & \multicolumn{2}{|c|}{$\begin{array}{c}\text { Relative } \\
\text { (Absolute/Average) } \\
(\%)\end{array}$} \\
\hline & VOD & GFC & VOD & GFC & VOD & GFC & VOD & GFC & VOD & GFC \\
\hline Argentina & 4517 & 3329 & 11.73 & 8.29 & 0.61 & 0.53 & $79^{*}$ & $358^{* *}$ & 1.68 & 11.00 \\
\hline Bolivia & 3045 & 2338 & 8.07 & 5.89 & 0.39 & 0.33 & $21^{*}$ & $166^{* * *}$ & 0.75 & 7.84 \\
\hline Brazil & 21926 & 27317 & 55.18 & 67.81 & 0.32 & 0.39 & $-1385^{* *}$ & $-1530^{* *}$ & -6.47 & -5.55 \\
\hline Chile & 173 & 408 & 0.50 & 1.04 & 0.12 & 0.30 & $35^{* *}$ & $17^{* * *}$ & 18.62 & 4.19 \\
\hline Colombia & 1899 & 1861 & 4.95 & 4.75 & 0.20 & 0.21 & $-2^{*}$ & $65^{* *}$ & -0.13 & 3.46 \\
\hline Ecuador & 450 & 305 & 1.24 & 0.79 & 0.18 & 0.15 & $-63^{* *}$ & $19^{* *}$ & -14.19 & 6.21 \\
\hline Fr. Guiana & 115 & 17 & 0.33 & 0.04 & 0.16 & 0.02 & $13^{* *}$ & $0^{*}$ & 11.08 & 1.18 \\
\hline Guyana & 288 & 50 & 0.75 & 0.13 & 0.16 & 0.03 & $-3^{*}$ & $0^{*}$ & -1.24 & -0.61 \\
\hline Peru & 1077 & 1047 & 3.06 & 2.69 & 0.12 & 0.13 & $52^{*}$ & $84^{* * *}$ & 4.46 & 8.24 \\
\hline Paraguay & 3030 & 2556 & 7.68 & 6.49 & 1.05 & 0.98 & $115^{*}$ & $213^{* * *}$ & 3.93 & 8.78 \\
\hline Surinam & 276 & 29 & 0.75 & 0.08 & 0.25 & 0.03 & $34^{* * *}$ & $2^{* *}$ & 12.57 & 8.69 \\
\hline Uruguay & 868 & 122 & 2.28 & 0.31 & 0.77 & 0.12 & $131^{*}$ & $18^{* * *}$ & 13.61 & 15.43 \\
\hline Venezuela & 1322 & 658 & 3.46 & 1.70 & 0.21 & 0.11 & $-148^{* * *}$ & $20^{*}$ & -13.65 & 3.12 \\
\hline Total & 38987 & 40038 & 100.00 & 100.00 & & & $-1121^{*}$ & $-568^{*}$ & -2.94 & -1.42 \\
\hline
\end{tabular}

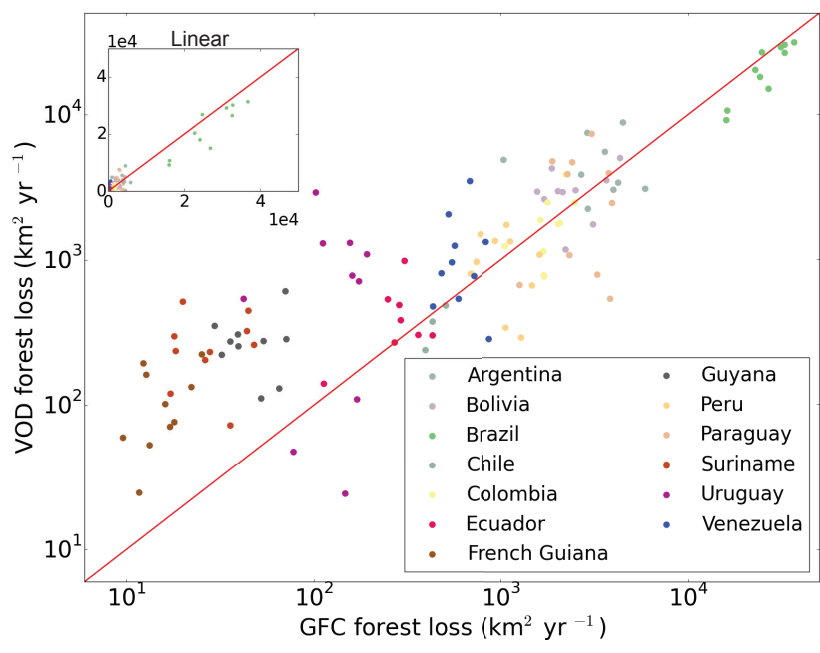

Figure 6. Country-level comparison of calibrated VOD and GFC forest loss based on annual totals (2001-2010). The inset shows the same data on a linear scale. The red lines depict the $1: 1$ line.

largest relative forest loss is Paraguay for both VOD (1.05\%) and GFC $(0.98 \%)$. In Fig. 7 we show these derived annual forest loss data from VOD for the full time period, along with GFC for 2001 through 2010. Obviously the average forest loss area for the overlapping period agrees between both data sets because our approach was tuned to match GFC, but the spatial and temporal variability can be different, potentially yielding new insights.
The main differences between VOD and GFC are thus that VOD estimates higher forest loss for the countries Uruguay, Paraguay and Chile compared to GFC. Furthermore, although VOD and GFC agreed on Brazil being the main driver of South American forest loss (54\% for VOD and $68 \%$ for GFC), VOD estimates show higher interannual variability in this. This is mainly the case in 2001, 2006 and 2009, where VOD estimated 36-41\% less Brazilian forest loss compared to GFC (Table 2).

The main feature in the GFC time series is the peak in 2004 (with values of 49000 and $58000 \mathrm{~km}^{2} \mathrm{yr}^{-1}$ for GFC and VOD respectively). VOD also shows this peak, but indicates that the two preceding years were high as well, making for a broader peak (2002-2004) with comparable values. The higher VOD values in 2002 and 2003 than GFC were mainly the result from higher estimated forest loss in Argentina and Paraguay. From 2005 onwards both data sets agreed on the decreasing forest loss rates and the interruptions in 2007 , 2008, and 2010, although the exact patterns differed.

Following Brazil, the countries with the highest forest loss were Argentina, Bolivia, Colombia, and Paraguay, each responsible for 5-8\% of total South American forest loss. The difference between VOD and GFC in relative contribution of each country to the total South American forest loss is on average $2 \%$, with the maximum difference of $13 \%$ for Brazil (all absolute differences, see Table 2). 

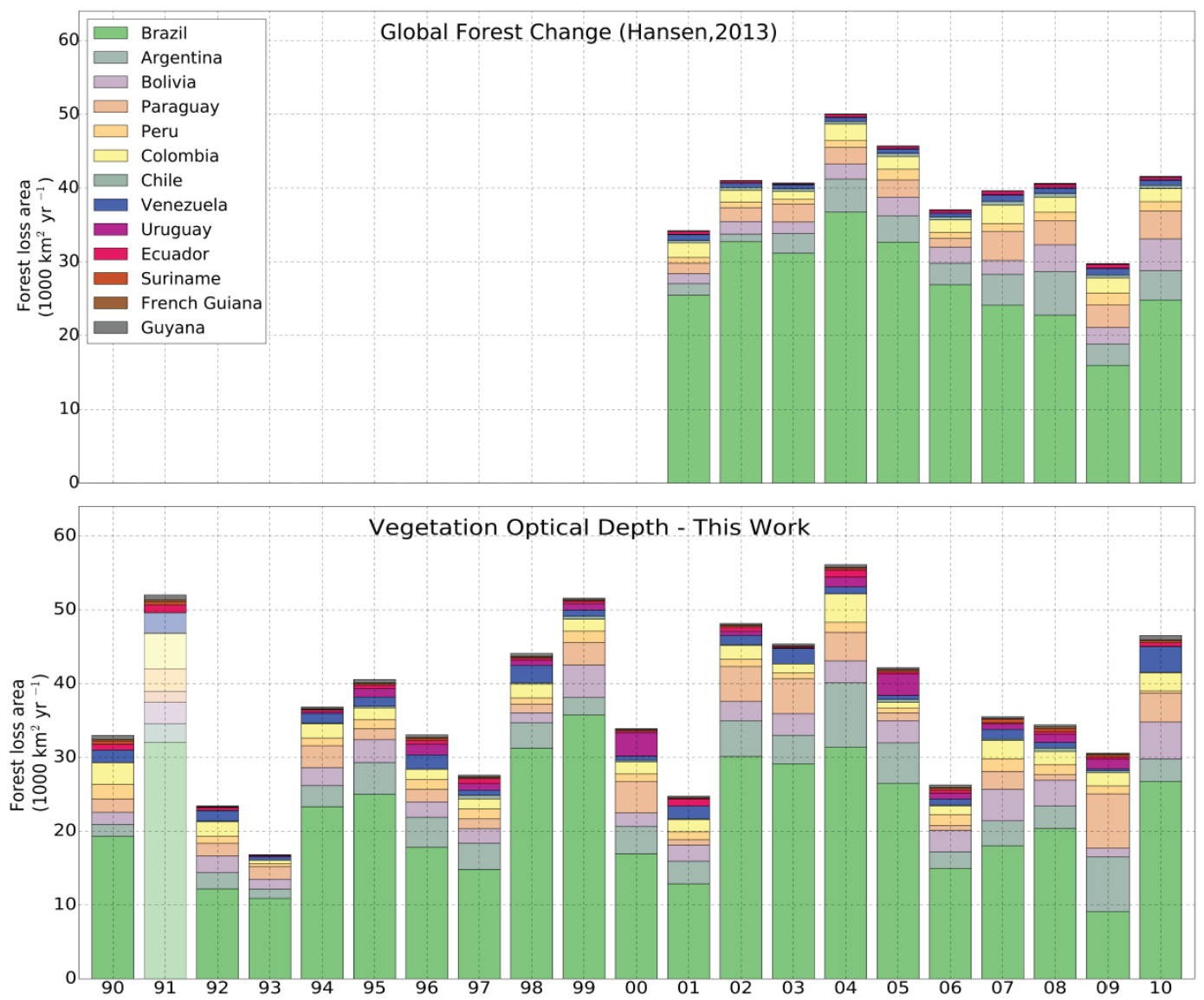

Figure 7. Country-level time series of annual totals of forest loss according to GFC (2001-2010) and VOD (1990-2010). VOD data are unreliable for 1991 as a result of the eruption of Mount Pinatubo.

\subsection{Country-level trends}

\subsubsection{1-2010}

To further compare VOD with GFC, we also calculated the trends per country, based on linear regression, over the 20012010 period in absolute values and as a percentage relative to their average forest loss over that time period (Table 2). It should be noted that not all the trends are statistically significant, partly because of the large interannual variability (Fig. 7, Table 2). The overall trend for all South American forest loss over the overlapping time period is negative for both data sets with a relative slope of -2.9 and $-1.4 \% \mathrm{yr}^{-2}$, for VOD and GFC respectively, which in absolute terms corresponds to -1121 and $-568 \mathrm{~km}^{2} \mathrm{yr}^{-2}$. For individual countries in general both data sets agreed and these trends were highly variable (Table 2).

\subsubsection{0-2010}

Focusing on the full time series, Fig. 7 indicates that totals of forest loss in South America were not stable or monotonically in- or decreasing. Instead, they appear to be highly dynamic - at least from a VOD perspective - especially during the first few years of our study period (1990-1994). After that, forest loss was fluctuating without a clear trend until about 2001, with 1991, 1995 and 1999 being high forest loss years. After this fluctuating stage a period with relatively high forest loss started, with 2002-2005 being four consecutive years with high forest loss. After 2005 forest loss decreased, with interruptions in 2007 and 2010 (Fig. 7).

We calculated the linear trends over the whole time period and the two decades 1990-2000 and 2000-2010 separately (Table 3). Over 1990-2010 Uruguay showed a clear relative increasing trend of almost $7 \% \mathrm{yr}^{-2}$ (in absolute values $60 \mathrm{~km}^{2} \mathrm{yr}^{-2}$ ). Over the same time period also $\mathrm{Ar}$ gentina, Chile, Paraguay, and Venezuela showed substantial in- or decreasing trends larger than $3 \% \mathrm{yr}^{-2}$. When investigating the decades 1990-2000 and 2000-2010 separately, additional patterns emerged. During the 1990s Argentina, Brazil, Colombia, Ecuador, and Uruguay had trends exceeding $5 \% \mathrm{yr}^{-2}$. During the 2000s, Brazil, Ecuador, and Surinam showed trends below $-5 \% \mathrm{yr}^{-2}$. The strongest differences per decade were found in Brazil (where the forest loss trend changed from $+9.8 \% \mathrm{yr}^{-2}$ in the 1990 s to 
Table 3. Trends in forest loss based on VOD for the whole time period (1990-2010) and the decades 1990-2000 and 2000-2010. Absolute values indicate the slope based on Pearson linear regression and the relative values are the absolute values relative to the average forest loss for that country over the full 21-year time period. Asterisks indicate the significance, where ${ }^{*}=p>0.25 ;^{* *}=p<0.25 ;{ }^{* * *}=p<0.05$.

\begin{tabular}{lrrrrrrrr}
\hline & \multicolumn{2}{c}{ Slope 1990-2010 } & \multicolumn{2}{c}{ Slope 1990-2000 } & \multicolumn{2}{c}{ Slope 2000-2010 } & \multicolumn{2}{c}{ Difference 2000s-1990s } \\
\hline & $\mathrm{km}^{2} \mathrm{yr}^{-2}$ & $\%$ & $\mathrm{~km}^{2} \mathrm{yr}^{-2}$ & $\%$ & $\mathrm{~km}^{2} \mathrm{yr}^{-2}$ & $\%$ & $\mathrm{~km}^{2} \mathrm{yr}^{-2}$ & $\%$ \\
\hline Argentina & $170^{* * *}$ & 4.58 & $182^{* *}$ & 5.76 & $109^{*}$ & 3.43 & -73 & -2.32 \\
Bolivia & $49^{* *}$ & 1.92 & $92^{*}$ & 0.75 & $72^{*}$ & 0.59 & -20 & -0.16 \\
Brazil & $-59^{*}$ & -0.27 & $1078^{*}$ & 9.79 & $-765^{*}$ & -6.95 & -1843 & -16.74 \\
Chile & $9^{* *}$ & 5.23 & $35^{* * *}$ & 3.34 & $23^{* *}$ & 2.21 & -12 & -1.13 \\
Colombia & $-36^{*}$ & -1.88 & $-197^{* *}$ & -16.69 & $10^{*}$ & 0.88 & 208 & 17.57 \\
Ecuador & $-12^{*}$ & -2.67 & $-42^{* *}$ & -14.85 & $-35^{*}$ & -12.58 & 6 & 2.27 \\
Fr. Guiana & $0^{*}$ & -0.31 & $-8^{*}$ & -3.76 & $13^{* * *}$ & 6.34 & 21 & 10.10 \\
Guyana & $-8^{* *}$ & -2.72 & $-16^{*}$ & -2.12 & $4^{*}$ & 0.50 & 20 & 2.61 \\
Peru & $-23^{*}$ & -1.79 & $-85^{*}$ & -4.55 & $45^{* *}$ & 2.39 & 130 & 6.94 \\
Paraguay & $98^{* *}$ & 3.99 & $32^{*}$ & 2.35 & $12^{*}$ & 0.86 & -21 & -1.49 \\
Surinam & $5^{*}$ & 2.25 & $-421^{* *}$ & -4.03 & $31^{* * *}$ & 5.91 & 53 & 9.94 \\
Uruguay & $60^{* * *}$ & 6.99 & $130^{* * *}$ & 11.91 & $-23^{*}$ & -2.08 & -152 & -13.99 \\
Venezuela & $-50^{* * *}$ & -3.97 & $-57^{*}$ & -0.30 & $-80^{* *}$ & -0.42 & -23 & -0.12 \\
\hline Total & $204^{*}$ & 0.55 & $1122^{*}$ & 3.01 & $-584^{*}$ & -1.57 & -1706 & -4.58 \\
\hline
\end{tabular}

$-7 \% \mathrm{yr}^{-2}$ in the 2000s) Colombia $\left(-16.7\right.$ to $\left.0.88 \% \mathrm{yr}^{-2}\right)$, and in Uruguay $\left(+11.9\right.$ to $\left.-2.1 \% \mathrm{yr}^{-2}\right)$ (Table 3). Other countries with substantial different trends between the two periods were Argentina 5.8 to $3.4 \% \mathrm{yr}^{-2}$ ), French Guiana $\left(-3.8\right.$ to $\left.6.3 \% \mathrm{yr}^{-2}\right)$, Peru $\left(-4.6\right.$ to $\left.2.4 \% \mathrm{yr}^{-2}\right)$, and Surinam $\left(-4\right.$ to $\left.5.9 \% \mathrm{yr}^{-2}\right)$.

\subsection{Brazilian state-level comparison with PRODES}

In addition to a comparison on the country scale, we also compared our results for the Brazilian states within the legal Amazon using the PRODES data set (Fig. 8). PRODES covers a longer period than GFC, but provides only data for the Legal Amazon. We do not expect PRODES and our data set to compare perfectly given that PRODES detects only deforestation of primary forests and VOD detects deforestation, degradation, and regrowth including forest loss of secondary forest. Nevertheless, the Pearson's $r^{2}$ over the full 21-year time period between these two data sets was $0.60(p<0.001)$ with a RMSE of $1.6 \times 10^{3} \mathrm{~km}^{2} \mathrm{yr}^{-1}$ on a state level.

Our results show for the Brazilian states a highly dynamic pattern with no steadily in- or decreasing trend (Fig. 8). The most notable difference between both data sets is that VOD suggest that 1991, 1999, 2002, and 2010 were high forest loss years, which PRODES did not show. Furthermore, PRODES showed increasing deforestation from 2002 until a peak in 2004, whereas VOD peaked in 2005. While there are substantial differences in the temporal variability in the VOD and PRODES data sets, they do agree on where most forest loss occurred: Pará and Mato Grosso. Combined, these two states were responsible for 69 and $61 \%$, for PRODES and VOD respectively, of all Brazilian Legal Amazon deforestation (PRODES) and forest loss (VOD). The total av-
Table 4. Average error for the Brazilian states. The error is defined as the VOD minus GFC forest loss area expressed as a percentage of GFC forest loss for the overlapping time period per state in the Legal Amazon.

\begin{tabular}{ll}
\hline State & $\begin{array}{l}\text { (VOD-GFC) / } \\
\text { GFC (mean \% } \mathrm{yr}^{-1} \text { ) }\end{array}$ \\
\hline Acre & 17 \\
Amapá & 50 \\
Amazonas & 399 \\
Maranhâo & 17 \\
Mato Grosso & 35 \\
Pará & 94 \\
Rondônia & 37 \\
Roraima & 705 \\
Tocantins & 2 \\
\hline
\end{tabular}

erage forest loss in the Legal Amazon from 1990 through 2010 (excluding 1993, which is missing in PRODES) was $16.6 \times 10^{3}$ and $15.2 \times 10^{3} \mathrm{~km}^{2} \mathrm{yr}^{-1}$ for PRODES and VOD respectively. The states with largest relative differences between VOD forest loss and PRODES deforestation are Amazonas and Roraima, with 1307 and $499 \mathrm{~km}^{2} \mathrm{yr}^{-1}$ respectively. These regions have little forest loss. The gridded errors for these states for VOD compared with GFC for the overlapping time period are relatively large: 705 and 399\% for Amazonas and Roraima respectively (Fig. 4, Table 4).

\subsection{Sensitivity Analysis}

Our forest loss detection approach was based on several assumptions, and we tested how sensitive our results are to two 

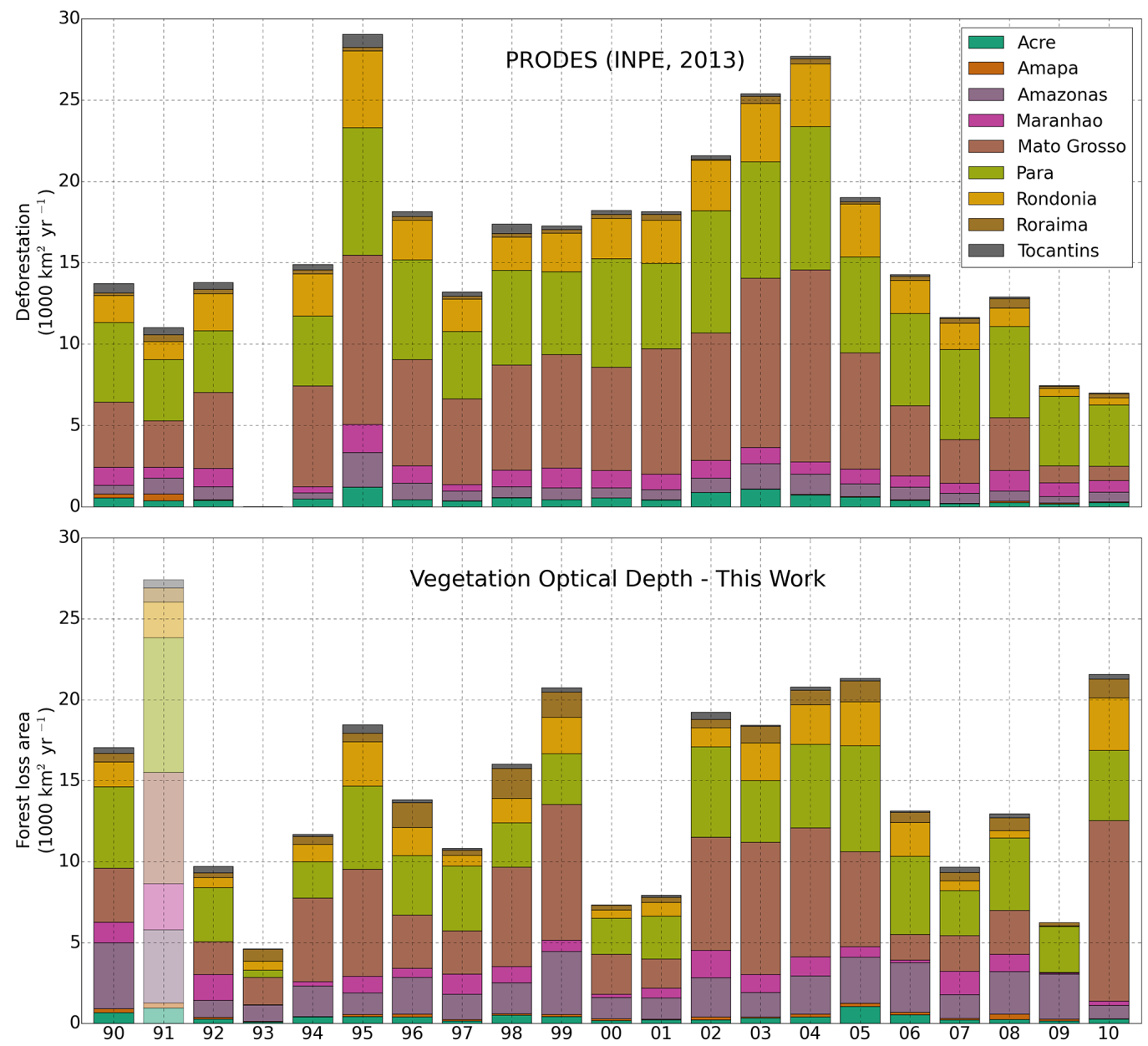

Figure 8. Time series of deforestation (PRODES) and forest loss area (VOD) for the Brazilian states in the Amazon (1990-2010). PRODES deforestation data are missing for 1993. VOD data are unreliable for 1991 as a result of the eruption of Mount Pinatubo.

main assumptions. First we tested whether the way we used the $t$ test (i.e. group 1 consists of all data until IYD is negative and group 2 consists of all data after this moment) is valid, or whether a fixed or smaller time period would capture forest loss better. The main reason to test this is that based on our method, group sizes in the $t$ test are not equal and group 2 could become so large, that recovery of vegetation could have taken place. Therefore we performed the same detection method, but now with the $t$ test group sizes fixed to 12, 24, or 36 months. This implies that the detectable time period changed to 1990-2010, 1991-2009, and 19922008 for the three different group sizes. The results showed for both the country-level analysis and the state-level analysis that our original method (without a fixed time period) yielded the highest correlations with GFC and PRODES. In general we found that correlation decreased with decreasing group sizes.

Besides the $t$ test group sizes, we also tested whether excluding grid cells that were not normally distributed would make a difference. This was done because a $t$ test requires normally distributed data. We tested three scenarios.

1. The standard scenario, where we excluded grid cells where the total average VOD was either larger than 1.2 or below 0.6, and GLWD was larger than $50 \%$.

2. As scenario 1, but we also excluded grid cells that were not normally distributed $(p=0.10)$.

3. As scenario 1, but we also excluded grid cells that were not normally distributed $(p=0.05)$

Excluding these not-normally distributed grid cells in scenarios 2 and 3 implied that respectively 25 and $32 \%$ of the total South American forest loss based on GFC would be missed. However, the Pearson's $r^{2}$ for all three scenarios stayed at 0.90 . Based on these results we assumed that excluding the not-normally distributed points did not have an effect on the large-scale country-level analysis and we used all grid cells based on scenario 1 in our analysis. 


\section{Discussion}

Our results indicated that the patterns of forest loss changed over both space and time, although the well-known arc of deforestation remained the single largest feature in South America over our full study period. Our results agree with earlier work showing that forest loss area, and probably also carbon emissions, declined after peaking in the year 2004 (Food and Agriculture Organization of the United Nations, 2010; Macedo et al., 2012; Malhi et al., 2008; Nepstad et al., 2009). This decrease in forest loss is observed mainly because Brazil reduced forest loss through a combination of conservation policies (law enforcement, expansion of the governmental protection of the Amazon area, and strict control of these enforcement by suspension of credit to landowners violating the rules) and because of changes in prices of agricultural outputs from 2005 onwards (Nepstad et al., 2009).

While forest loss in the arc of deforestation, the region around the southern border of Mato Grosso do Sul (Fig. 3a, label 2) and the region around Manaus (Fig. 3a, label 3), declined after 2004, in the Gran Chaco region (Fig. 3a, label 1) it increased over the time, as shown earlier by Chen et al. (2013). In this region the observed forest loss is in areas where deciduous broadleaf forest $(>10 \mathrm{~m}$ tall) with closed canopy is converted to shorter $(<10 \mathrm{~m})$ Chacoan woodlands and agricultural areas (Steininger et al., 2001) and could be related to soy bean production in this region (Boletta et al., 2006; Gasparri and Grau, 2009; Zak et al., 2004). This is in line with our trends and time series (Fig. 7, Table 2) in which both VOD and GFC show an increasing trend for Argentina over 2001-2010, whereas a decreasing trend over that time period occurred in Brazil (Table 2). One explanation could be the relocation of agricultural hotspots because of the strict forest law and effective forest law enforcement within Brazil (Dobrovolski and Rattis, 2014).

The spatial pattern of forest loss in Northern Brazil in the states of Amazonas and Roraima (Fig. 3, label 3) can partly be explained by forest fires (Fearnside, 2000); the peak during the 1995-2000 time period for example could be caused by the El Niño drought fire events during 1997 and 1998 (Barbosa and Fearnside, 1999). This is supported by fire emissions estimates for this region derived from the Global Fire Emissions Database (van der Werf et al., 2010). During these droughts, man-made fires destroyed millions of hectares of fragmented and natural forest (Laurance, 1998). This increase that continued during the 2000s in Amazonas and Roraima is not seen anymore in the country-level time series (Fig. 7), because these changes are relatively small compared to the changes in the arc of deforestation.

In the country-level analysis between VOD and GFC the latter indicates higher average South American forest loss, with a difference of $3126 \mathrm{~km}^{2} \mathrm{yr}^{-1}$ or $7.6 \% \mathrm{yr}^{-1}$ of average VOD forest loss. The country with the largest absolute contribution in both data sets is Brazil. In GFC Brazil had a
$10 \%$ larger contribution to the South American total forest loss than in VOD. This could be caused by the difference in what both GFC and VOD measure. GFC measures gross forest loss while, due to our methodology, VOD yields net forest loss. In areas with much regrowth, VOD will therefore underestimate forest loss compared to GFC. This also has the consequence that VOD is most reliable in areas where deforestation is the dominant change. Another reason could be the different spatial resolutions of the satellite products that the data sets are based on. GFC is based on Landsat, which has a spatial resolution of $30 \mathrm{~m}$ and can capture many small-scale forest loss events which will be missed in our data set based on VOD with its much coarser $0.25^{\circ}$ resolution. The difference in spatial resolution could also be the reason why other countries, such as Chile, show less forest loss and higher interannual variability in VOD than in GFC, and why countries with relatively little forest loss, such as Uruguay, Surinam, French Guiana, and Guyana had more forest loss based on VOD (Fig. 6). In Uruguay many forest plantations occur (Fig. 1 in the Supplement of Achard et al., 2014) and the result of these plantations is that forest loss is often of small scale. This, in combination with the overestimation of VOD with smaller scale forest loss, could explain why Uruguay shows so much higher values at the country level, although additional research is required to better understand these differences. While we would in general favour GFC over VOD during the overlapping periods for the reasons mentioned above, the temporal resolution of VOD is superior to any other data set for our study period from 1990-2010. For areas with frequent cloud cover where Landsat may have difficulties in acquiring reliable data, VOD may be in a better position to map forest loss.

We also compared our results for the whole time period from 1990 through 2010 with PRODES data in a state-level comparison, and they had a Pearson $r^{2}$ of 0.66 . As mentioned earlier, to some degree the comparison is one of apples and oranges because PRODES provides annual estimates of deforestation in pixels where no deforestation has occurred before, whereas the VOD data set will give information about deforestation and degradation and potentially regrowth. Although forest loss based on VOD includes degradation and regrowth, PRODES shows on average over the whole time period $1451 \mathrm{~km}^{2} \mathrm{yr}^{-1}\left(9.6 \% \mathrm{yr}^{-1}\right.$ of the total average legal Amazon forest loss according to VOD) more deforestation than VOD. This could be caused by the differences in methodology and spatial resolution of both data sets we mentioned before, but also potential inconsistencies in PRODES could play a role; until 2002 PRODES was based on visual interpretation, after which PRODES digital was used. On a state-level VOD overestimates forest loss area in the states of Amazonas and Roraima, which is mostly related to the relatively low and small-scale forest loss in these states (Fig. 4, Table 4).

One of the most striking differences between VOD and PRODES were the years 1991, 1999 and 2010 when VOD 
was much higher than PRODES. The underlying reasons may not be directly related to forest loss. In 1991 this difference could be explained by the eruption of Mount Pinatubo, which had the result that led to increased VOD in the Tropics (Kobayashi and Dye, 2005; Liu et al., 2011a). The peak in 1999 in VOD was mainly caused by an increase in the state of Amazonas. During 1999 heavy flooding occurred in this region (Chen et al., 2010). Since VOD is sensitive to large waters, the VOD signal could have been influenced by this event. Finally, the peak in 2010 could be caused by the drought that hit the Amazon that year (Lewis et al., 2011). Amazon forests are sensitive to increasing moisture stress and this could affect aboveground biomass (Phillips et al., 2009). This supports the findings of Liu et al. (2012), who noticed that VOD responded to interannual variability in precipitation for tropical regions. However, this 2010 peak in forest loss was also detected by GFC. PRODES did not show this peak, partly because it was related to secondary forest degradation and deforestation, which is not captured by PRODES (Fanin and van der Werf, 2015). This indicates the need to better reconcile the differences between these various estimates and not rely on one single data set.

\section{Conclusions}

We have used a new satellite-based data set using microwave observations to estimate forest loss in South America for the 1990-2010 period in a consistent manner. Our approach may have difficulties in capturing small-scale forest loss and may be impacted on interannual scales by anomalous dry or wet conditions, and is therefore most useful for regional, longterm assessments. The long study period of our study enabled us to improve on characterizing the spatiotemporal dynamic nature of forest loss. Our results confirm the well-known decrease of forest loss in the Brazilian Amazon since 2005, but indicate no trend over the full time period for our whole study region. In the regions south of the arc of deforestation, however, forest loss has increased over the full time period. This includes Argentina, Bolivia, Chile, and Paraguay where trends up to $4 \% \mathrm{yr}^{-2}$ were observed over 1990-2010, partly offsetting the reductions in forest loss in Brazil.

Each of the data sets used here has limitations for mapping forest loss including length of time period (GFC), limited spatial domain, and focus on detecting only pristine forest loss (PRODES), and coarse resolution and influence of anomalously dry and wet periods on the detected signal (VOD). This indicates that better understanding the differences between those, and other, forest loss data sets requires more scrutiny and that uncertainties are large when relying on one single data set. We presented a first attempt towards a better forest loss data set using VOD to better understand forest loss dynamics. The added value of our analysis is mostly providing new annual forest loss estimates during the 1990s, a period not covered by GFC, MODIS, and other satellite data sets. More research is needed to better under- stand what VOD exactly represents, potentially comparing with existing lidar-based benchmark data sets (Baccini et al., 2012; Saatchi et al., 2011).

Acknowledgements. We thank Douglas Morton, Jan Verbesselt, and Niels Andela for useful discussions. Furthermore, we acknowledge INPE and Matthew Hansen for making their data publicly available. We kindly thank two reviewers for their critical but constructive comments of an earlier version of this manuscript. This research was supported by the European Research Council grant number 280061 .

Edited by: M. Williams

\section{References}

Achard, F., Beuchle, R., Mayaux, P., Stibig, H.-J., Bodart, C., Brink A., Carboni, S., Desclée, B., Donnay, F., Eva, H. D., Lupi, A., Raši, R., Seliger, R. and Simonetti, D.: Determination of tropical deforestation rates and related carbon losses from 1990 to 2010, Glob. Change Biol., 20, 2540-2554, doi:10.1111/gcb.12605, 2014.

Andela, N., Liu, Y. Y., van Dijk, A. I. J. M., de Jeu, R. A. M., and McVicar, T. R.: Global changes in dryland vegetation dynamics (1988-2008) assessed by satellite remote sensing: comparing a new passive microwave vegetation density record with reflective greenness data, Biogeosciences, 10, 6657-6676, doi:10.5194/bg10-6657-2013, 2013.

Anyamba, A. and Tucker, C. J.: Analysis of Sahelian vegetation dynamics using NOAA-AVHRR NDVI data from 1981-2003, J. Arid Environ., 63, 596-614, 2005.

Asner, G. P.: Cloud cover in Landsat observations of the Brazilian Amazon, Int. J. Remote Sens., 22, 3855-3862, doi:10.1080/01431160010006926, 2001.

Baccini, A., Goetz, S. J., Walker, W. S., Laporte, N. T., Sun, M., Sulla-Menashe, D., Hackler, J., Beck, P. S. A., Dubayah, R., Friedl, M. A., Samanta, S. and Houghton, R. A.: Estimated carbon dioxide emissions from tropical deforestation improved by carbon-density maps, Nat. Clim. Chang., 2, 182-185, doi:10.1038/nclimate1354, 2012.

Barbosa, R. I. and Fearnside, P. M.: Incêndios na Amazõnia Brasileira: estimativa da emissão de gases do efeito estufa pela queima de diferentes ecossistemas de Roraima na passagem do evento "El Niño" (1997/1998), Acta Amaz., 29, 513-534, 1999.

Boletta, P. E., Ravelo, A. C., Planchuelo, A. M., and Grilli, M.: Assessing deforestation in the Argentine Chaco, Forest Ecol Manag., 228, 108-114, doi:10.1016/j.foreco.2006.02.045, 2006.

Broich, M., Hansen, M., Stolle, F., Potapov, P., Margono, B. A., and Adusei, B.: Remotely sensed forest cover loss shows high spatial and temporal variation across Sumatera and Kalimantan, Indonesia 2000-2008, Environ. Res. Lett., 6, 014010, doi:10.1088/1748-9326/6/1/014010, 2011.

Chen, J. L., Wilson, C. R., and Tapley, B. D.: The 2009 exceptional Amazon flood and interannual terrestrial water storage change observed by GRACE, Water Resour. Res., 46, 1-10, doi:10.1029/2010WR009383, 2010. 
Chen, Y., Morton, D. C., Jin, Y., Collatz, G. J., Kasibhatla, P. S., van der Werf, G. R., DeFries, R. S., and Randerson, J. T.: Longterm trends and interannual variability of forest, savanna and agricultural fires in South America, Carbon Manag., 4, 617-638, doi:10.4155/cmt.13.61, 2013.

Costa, M. H. and Foley, J. A.: A comparison of precipitation datasets for the Amazon Basin, Geophys. Res. Lett., 25, 155158, doi:10.1029/97GL03502, 1998.

de Jeu, R. A. M., Holmes, T. R. H., Parinussa, R. M., and Owe, M.: A spatially coherent global soil moisture product with improved temporal resolution, J. Hydrol., 516, 284-296, doi:10.1016/j.jhydrol.2014.02.015, 2014.

de Jong, R., Verbesselt, J., Zeileis, A., and Schaepman, M. E.: Shifts in global vegetation activity trends, Remote Sens., 5, 1117-1133, doi:10.3390/rs5031117, 2013.

Dobrovolski, R. and Rattis, L.: Brazil should help developing nations to foster agriculture and environmental protection, Front. Ecol. Environ., 12, 376-376, doi:10.1890/14.WB.010, 2014.

Ernst, C., Mayaux, P., Verhegghen, A., Bodart, C., Christophe, M., and Defourny, P.: National forest cover change in Congo Basin: Deforestation, reforestation, degradation and regeneration for the years 1990, 2000 and 2005, Glob. Change Biol., 19, 1173-1187, doi:10.1111/gcb.12092, 2013.

Eva, H. D., Achard, F., Beuchle, R., de Miranda, E., Carboni, S., Seliger, R., Vollmar, M., Holler, W. a., Oshiro, O. T., Arroyo, V. B., and Gallego, J.: Forest cover changes in tropical south and Central America from 1990 to 2005 and related carbon emissions and removals, Remote Sens., 4, 1369-1391, doi:10.3390/rs4051369, 2012.

Fanin, T. and van der Werf, G. R.: Relationships between burned area, forest cover loss, and land cover change in the Brazilian Amazon based on satellite data, Biogeosciences, 12, 6033-6043, doi:10.5194/bg-12-6033-2015, 2015.

FAO: Global Forest Resources Assessment 2005: Progress towards sustainable forest management, Food and Agricultural Organization of the United Nations, Rome, Italy, 2006.

Fearnside, P. M.: Global Warming and Tropical Land-Use Change: Greenhouse Gas Emissions from Biomass Burning, Decomposition and Soils in Forest Conversion, Shifting Cultivation and Secondary Vegetation, Clim. Change, 46, 115-158, doi:10.1023/A:1005569915357, 2000.

Fearnside, P. M.: Deforestation in Brazilian Amazonia: History, Rates, and Consequences, Conserv. Biol., 19, 680-688, doi:10.1111/j.1523-1739.2005.00697.x, 2005.

Food and Agriculture Organization of the United Nations: Global forest resources assessments main report, FAO For. Pap., 163, available at: http://www.fao.org/docrep/013/i1757e/ i1757e00.htm (last access: 27 January 2016), 2010.

Frolking, S., Hagen, S., Milliman, T., Palace, M., Shimbo, J. Z., and Fahnestock, M.: Detection of Large-Scale Forest Canopy Change in Pan-Tropical Humid Forests 2000-2009 With the SeaWinds Ku-Band Scatterometer, IEEE T. Geosci. Remote, 50, 26032617, doi:10.1109/TGRS.2011.2182516, 2012.

Gasparri, N. I. and Grau, H. R.: Deforestation and fragmentation of Chaco dry forest in NW Argentina (1972-2007), Forest Ecol. Manag., 258, 913-921, doi:10.1016/j.foreco.2009.02.024, 2009.

Geist, H. J. and Lambin, E. F.: Proximate Causes and Underlying Driving Forces of Tropical Deforesta- tion, Bioscience, 52, 143-150, doi:10.1641/00063568(2002)052[0143:PCAUDF]2.0.CO;2, 2002.

Grainger, A.: Difficulties in tracking the long-term global trend in tropical forest area., P. Natl. Acad. Sci. USA, 105, 818-23, doi:10.1073/pnas.0703015105, 2008.

Grau, H. R., Gasparri, N. I., and Aide, T. M.: Agriculture expansion and deforestation in seasonally dry forests of north-west Argentina, Environ. Conserv., 32, 140-148, doi:10.1017/S0376892905002092, 2005.

Guan, K., Wood, E. F., and Caylor, K. K.: Multi-sensor derivation of regional vegetation fractional cover in Africa, Remote Sens. Environ., 124, 653-665, doi:10.1016/j.rse.2012.06.005, 2012.

Hansen, M. C., Stehman, S. V., and Potapov, P. V.: Quantification of global gross forest cover loss., P. Natl. Acad. Sci. USA, 107, 8650-8655, doi:10.1073/pnas.0912668107, 2010.

Hansen, M. C., Potapov, P. V., Moore, R., Hancher, M., Turubanova, S. A., Tyukavina, A., Thau, D., Stehman, S. V, Goetz, S. J., Loveland, T. R., Kommareddy, A., Egorov, A., Chini, L., Justice, C. O., and Townshend, J. R. G.: High-resolution global maps of 21st-century forest cover change., Science, 342, 850853, doi:10.1126/science.1244693, 2013.

Harris, N. L., Brown, S., Hagen, S. C., Saatchi, S. S., Petrova, S., Salas, W., Hansen, M. C., Potapov, P. V., and Lotsch, A.: Baseline map of carbon emissions from deforestation in tropical regions. Science, 336, 1573-1576, doi:10.1126/science.1217962, 2012.

INPE: PRODES - Metodologia para o Cálculo da Taxa Anual de Desmatamento na Amazônia Legal, available at: http://www.obt. inpe.br/prodes/metodologia_TaxaProdes.pdf (last access: 27 January 2016), 2013.

Jackson, T. J. and Schmugge, T. J.: Vegetation effects on the microwave emission of soils, Remote Sens. Environ., 36, 203-212, doi:10.1016/0034-4257(91)90057-D, 1991.

Jones, M. O., Jones, L. A., Kimball, J. S., and McDonald, K. C.: Satellite passive microwave remote sensing for monitoring global land surface phenology, Remote Sens. Environ., 115, 1102-1114, doi:10.1016/j.rse.2010.12.015, 2011.

Joshi, N., Mitchard, E. T., Woo, N., Torres, J., Moll-Rocek, J., Ehammer, A., Collins, M., Jepsen, M. R., and Fensholt, R.: Mapping dynamics of deforestation and forest degradation in tropical forests using radar satellite data, Environ. Res. Lett., 10, 034014, doi:10.1088/1748-9326/10/3/034014, 2015.

Kerr, Y. H. and Njoku, E. G.: Semiempirical model for interpreting microwave emission from semiarid land surfaces as seen from space, IEEE T. Geosci. Remote, 28, 384-393, doi:10.1109/36.54364, 1990.

Kim, D.-H., Sexton, J. O., and Townshend, J. R.: Accelerated deforestation in the humid tropics from the 1990s to the 2000s, Geophys. Res. Lett., 42, 3495-3501, doi:10.1002/2014GL062777, 2015.

Kirdiashev, K. P., Chukhlantsev, A. A., and Shutko, A. M.: Microwave radiation of the earth's surface in the presence of vegetation cover, Radio Eng. Electron. P., 24, 256-264, 1979.

Kobayashi, H. and Dye, D. G.: Atmospheric conditions for monitoring the long-term vegetation dynamics in the Amazon using normalized difference vegetation index, Remote Sens. Environ., 97, 519-525, doi:10.1016/j.rse.2005.06.007, 2005.

Koh, L. P., Miettinen, J., Liew, S. C., and Ghazoul, J.: Remotely sensed evidence of tropical peatland conversion 
to oil palm., P. Natl. Acad. Sci. USA, 108, 5127-5132, doi:10.1073/pnas.1018776108, 2011.

Laurance, W. F.: A crisis in the making: Responses of Amazonian forests to land use and climate change, Trends Ecol. Evol., 13, 411-415, doi:10.1016/S0169-5347(98)01433-5, 1998.

Lehner, B. and Döll, P.: Development and validation of a global database of lakes, reservoirs and wetlands, J. Hydrol., 296, 1-22, doi:10.1016/j.jhydrol.2004.03.028, 2004.

Lewis, S. L., Brando, P. M., Phillips, O. L., van der Heijden, G. M. F., and Nepstad, D.: The 2010 Amazon drought, Science, 331, p. 554, doi:10.1126/science.1200807, 2011.

Liu, Y. Y., Evans, J. P., McCabe, M. F., de Jeu, R. A. M., van Dijk, A. I. J. M., Dolman, A. J., and Saizen, I.: Changing climate and overgrazing are decimating Mongolian steppes., PLoS One, 8, e57599, doi:10.1371/journal.pone.0057599, 2013.

Liu, Y. Y., de Jeu, R. A. M., McCabe, M. F., Evans, J. P., and van Dijk, A. I. J. M.: Global long-term passive microwave satellitebased retrievals of vegetation optical depth, Geophys. Res. Lett., 38, L18402, doi:10.1029/2011GL048684, 2011 a.

Liu, Y. Y., Parinussa, R. M., Dorigo, W. A., De Jeu, R. A. M., Wagner, W., van Dijk, A. I. J. M., McCabe, M. F., and Evans, J. P.: Developing an improved soil moisture dataset by blending passive and active microwave satellite-based retrievals, Hydrol. Earth Syst. Sci., 15, 425-436, doi:10.5194/hess-15-425-2011, 2011 b.

Liu, Y. Y., van Dijk, A. I. J. M., McCabe, M. F., Evans, J. P., and de Jeu, R. A. M.: Global vegetation biomass change (1988-2008) and attribution to environmental and human drivers, Global Ecol. Biogeogr., 22, 692-705, doi:10.1111/geb.12024, 2012.

Liu, Y. Y., van Dijk, A. I. J. M., de Jeu, R. A. M., Canadell, J. G., McCabe, M. F., Evans, J. P., and Wang, G.: Recent reversal in loss of global terrestrial biomass, Nat. Clim. Chang., 5, 470-474, doi:10.1038/nclimate2581, 2015.

Macedo, M. N., DeFries, R. S., Morton, D. C., Stickler, C. M., Galford, G. L. and Shimabukuro, Y. E.: Decoupling of deforestation and soy production in the southern Amazon during the late 2000s, P. Natl. Acad. Sci. USA, 109, 1341-1346, doi:10.1073/pnas.1111374109, 2012.

Malhi, Y.: The carbon balance of tropical forest regions, 1990-2005, Curr. Opin. Environ. Sustain., 2, 237-244, doi:10.1016/j.cosust.2010.08.002, 2010.

Malhi, Y., Roberts, J. T., Betts, R. A., Killeen, T. J., Li, W., and Nobre, C. A.: Climate change, deforestation, and the fate of the Amazon, Science, 319, 169-172, doi:10.1126/science.1146961, 2008.

Mayaux, P., Achard, F., and Malingreau, J.-P.: Global tropical forest area measurements derived from coarse resolution satellite imagery: a comparison with other approaches, Environ. Conserv., 25, 37-52, doi:10.1017/S0376892998000083, 1998.

Meesters, A. G. C. A., De Jeu, R. A. M., and Owe, M.: Analytical derivation of the vegetation optical depth from the microwave polarization difference index, IEEE Geosci. Remote S., 2, 121123, doi:10.1109/LGRS.2005.843983, 2005.

Mitchard, E. T. A., Saatchi, S. S., White, L. J. T., Abernethy, K. A., Jeffery, K. J., Lewis, S. L., Collins, M., Lefsky, M. A., Leal, M. E., Woodhouse, I. H., and Meir, P.: Mapping tropical forest biomass with radar and spaceborne LiDAR in Lopé National Park, Gabon: overcoming problems of high biomass and persistent cloud, Biogeosciences, 9, 179-191, doi:10.5194/bg-9-1792012, 2012.
Mo, T., Choudhury, B. J., Schmugge, T. J., Wang, J. R., and Jackson, T. J.: A model for microwave emission from vegetation-covered fields, J. Geophys. Res., 87, 11229, doi:10.1029/JC087iC13p11229, 1982.

Morton, D. C., DeFries, R. S., Shimabukuro, Y. E., Anderson, L. O., Del Bon Espírito-Santo, F., Hansen, M., and Carroll, M.: Rapid Assessment of Annual Deforestation in the Brazilian Amazon Using MODIS Data, Earth Interact., 9, 1-22, doi:10.1175/EI139.1, 2005.

Morton, D. C., Defries, R. S., Randerson, J. T., Giglio, L., Schroeder, W., and van der Werf, G. R.: Agricultural intensification increases deforestation fire activity in Amazonia, Glob. Change Biol., 14, 2262-2275, doi:10.1111/j.13652486.2008.01652.x, 2008.

Myneni, R. B., Hall, F. G., Sellers, P. J., and Marshak, A. L.: The interpretation of spectral vegetation indexes, IEEE T. Geosci. Remote, 33, 481-486, doi:10.1109/36.377948, 1995.

Naylor, R., Steinfeld, H., Falcon, W., Galloway, J., Smil, V., Bradford, E., Alder, J., and Mooney, H.: Agriculture. Losing the links between livestock and land, Science, 310, 1621-1622, doi:10.1126/science.1117856, 2005.

Nepstad, D., Soares-Filho, B. S., Merry, F., Lima, A., Moutinho, P., Carter, J., Bowman, M., Cattaneo, A., Rodrigues, H., Schwartzman, S., McGrath, D. G., Stickler, C. M., Lubowski, R., PirisCabezas, P., Rivero, S., Alencar, A., Almeida, O., and Stella, O. Environment. The end of deforestation in the Brazilian Amazon, Science, 326, 1350-1351, doi:10.1126/science.1182108, 2009.

Owe, M., de Jeu, R. A. M., and Walker, J. P.: A methodology for surface soil moisture and vegetation optical depth retrieval using the microwave polarization difference index, IEEE T. Geosci. Remote, 39, 1643-1654, doi:10.1109/36.942542, 2001.

Owe, M., de Jeu, R. A. M., and Holmes, T.: Multisensor historical climatology of satellite-derived global land surface moisture, J. Geophys. Res., 113, F01002, doi:10.1029/2007JF000769, 2008.

Pan, Y., Birdsey, R. A., Fang, J., Houghton, R., Kauppi, P. E., Kurz, W. A., Phillips, O. L., Shvidenko, A., Lewis, S. L., Canadell, J. G., Ciais, P., Jackson, R. B., Pacala, S. W., McGuire, A. D., Piao, S., Rautiainen, A., Sitch, S., and Hayes, D.: A large and persistent carbon sink in the world's forests., Science, 333, 988 993, doi:10.1126/science.1201609, 2011.

Phillips, O. L., Aragão, L. E. O. C., Lewis, S. L., Fisher, J. B., Lloyd, J., López-González, G., Malhi, Y., Monteagudo, A., Peacock, J., Quesada, C. A., van der Heijden, G., Almeida, S., Amaral, I., Arroyo, L., Aymard, G., Baker, T. R., Bánki, O., Blanc, L., Bonal, D., Brando, P., Chave, J., de Oliveira, A. C. A., Cardozo, N. D., Czimczik, C. I., Feldpausch, T. R., Freitas, M. A., Gloor, E., Higuchi, N., Jiménez, E., Lloyd, G., Meir, P., Mendoza, C., Morel, A., Neill, D. A., Nepstad, D., Patiño, S., Peñuela, M. C., Prieto, A., Ramírez, F., Schwarz, M., Silva, J., Silveira, M., Thomas, A. S., Steege, H. Ter, Stropp, J., Vásquez, R., Zelazowski, P., Alvarez Dávila, E., Andelman, S., Andrade, A., Chao, K., Erwin, T., Di Fiore, A., Honorio C, E., Keeling, H., Killeen, T. J., Laurance, W. F., Peña Cruz, A., Pitman, N. C. A., Núñez Vargas, P., Ramírez-Angulo, H., Rudas, A., Salamão, R., Silva, N., Terborgh, J. and Torres-Lezama, A.: Drought sensitivity of the Amazon rainforest, Science, 323, 1344-1347, doi:10.1126/science.1164033, 2009.

Potapov, P. V., Turubanova, S. A., Hansen, M. C., Adusei, B., Broich, M., Altstatt, A., Mane, L., and Justice, C. O.: Quanti- 
fying forest cover loss in Democratic Republic of the Congo, 2000-2010, with Landsat ETM+ data, Remote Sens. Environ., 122, 106-116, doi:10.1016/j.rse.2011.08.027, 2012.

Poulter, B., Frank, D., Ciais, P., Myneni, R. B., Andela, N., Bi, J., Broquet, G., Canadell, J. G., Chevallier, F., Liu, Y. Y., Running, S. W., Sitch, S., and van der Werf, G. R.: Contribution of semiarid ecosystems to interannual variability of the global carbon cycle., Nature, 509, 600-603, doi:10.1038/nature13376, 2014.

Saatchi, S. S., Harris, N. L., Brown, S., Lefsky, M., Mitchard, E. T. A., Salas, W., Zutta, B. R., Buermann, W., Lewis, S. L., Hagen, S., Petrova, S., White, L., Silman, M., and Morel, A.: Benchmark map of forest carbon stocks in tropical regions across three continents., P. Natl. Acad. Sci. USA, 108, 9899-9904, doi:10.1073/pnas.1019576108, 2011.

Shi, J., Jackson, T., Tao, J., Du, J., Bindlish, R., Lu, L., and Chen, K. S.: Microwave vegetation indices for short vegetation covers from satellite passive microwave sensor AMSR-E, Remote Sens. Environ., 112, 4285-4300, doi:10.1016/j.rse.2008.07.015, 2008.

Shimabukuro, Y. E., Batista, G. T., Mello, E. M. K., Moreira, J. C., and Duarte, V.: Using shade fraction image segmentation to evaluate deforestation in Landsat Thematic Mapper images of the Amazon Region, Int. J. Remote Sens., 19, 535-541, doi:10.1080/014311698216152, 1998.

Steininger, M. K., Tucker, C. J., Townshend, J. R. G., Killeen, T. J., Desch, A., Bell, V., and Ersts, P.: Tropical deforestation in the Bolivian Amazon, Environ. Conserv., 28, 127-134, doi:10.1017/S0376892901000133, 2001.

Tucker, C., Pinzon, J., Brown, M., Slayback, D., Pak, E., Mahoney, R., Vermote, E., and El Saleous, N.: An extended AVHRR 8-km NDVI dataset compatible with MODIS and SPOT vegetation NDVI data, Int. J. Remote Sens., 26, 4485-4498, doi:10.1080/01431160500168686, 2005.

UNFCCC: Annex to UNFCCC decision 16/CMP.1 Land use, land-use change and forestry, Rep. Conf. Parties Serv. as Meet. Parties to Kyoto Protoc. its first Sess. held Montr. from 28 November to 10 December 2005, FCCC/KP/CM, 3, available at: http://unfccc.int/resource/docs/2005/cmp1/eng/ 08a03.pdf\#page=3 (last access: 27 January 2016), 2006.
Verbesselt, J., Zeileis, A., and Herold, M.: Near real-time disturbance detection using satellite image time series, Remote Sens. Environ., 123, 98-108, doi:10.1016/j.rse.2012.02.022, 2012.

Verhegghen, A., Mayaux, P., de Wasseige, C., and Defourny, P.: Mapping Congo Basin vegetation types from $300 \mathrm{~m}$ and $1 \mathrm{~km}$ multi-sensor time series for carbon stocks and forest areas estimation, Biogeosciences, 9, 5061-5079, doi:10.5194/bg-9-50612012, 2012.

van der Werf, G. R., Morton, D. C., DeFries, R. S., Giglio, L., Randerson, J. T., Collatz, G. J., and Kasibhatla, P. S.: Estimates of fire emissions from an active deforestation region in the southern Amazon based on satellite data and biogeochemical modelling, Biogeosciences, 6, 235-249, doi:10.5194/bg-6-235-2009, 2009.

van der Werf, G. R., Randerson, J. T., Giglio, L., Collatz, G. J., Mu, M., Kasibhatla, P. S., Morton, D. C., DeFries, R. S., Jin, Y., and van Leeuwen, T. T.: Global fire emissions and the contribution of deforestation, savanna, forest, agricultural, and peat fires (19972009), Atmos. Chem. Phys., 10, 11707-11735, doi:10.5194/acp10-11707-2010, 2010.

Wasige, J. E., Groen, T. A., Smaling, E., and Jetten, V.: Monitoring basin-scale land cover changes in Kagera Basin of Lake Victoria using: Ancillary data and remote sensing, Int. J. Appl. Earth Obs., 21, 32-42, doi:10.1016/j.jag.2012.08.005, 2012.

Zak, M. R., Cabido, M., and Hodgson, J. G.: Do subtropical seasonal forests in the Gran Chaco, Argentina, have a future?, Biol. Conserv., 120, 589-598, doi:10.1016/j.biocon.2004.03.034, 2004.

Zhou, L., Tian, Y., Myneni, R. B., Ciais, P., Saatchi, S., Liu, Y. Y., Piao, S., Chen, H., Vermote, E. F., Song, C., and Hwang, T.: Widespread decline of Congo rainforest greenness in the past decade, Nature, 509, 86-90, doi:10.1038/nature13265, 2014.

Zhu, Z., Bi, J., Pan, Y., Ganguly, S., Anav, A., Xu, L., Samanta, A., Piao, S., Nemani, R. R., and Myneni, R. B.: Global data sets of vegetation leaf area index (LAI) $3 \mathrm{~g}$ and fraction of photosynthetically active radiation (FPAR) $3 \mathrm{~g}$ derived from global inventory modeling and mapping studies (GIMMS) normalized difference vegetation index (NDVI3G) for the period 1981 to 2, Remote Sens., 5, 927-948, doi:10.3390/rs5020927, 2013. 